\title{
Classification of heparinolytic bacteria into a new genus, Pedobacter, comprising four species: Pedobacter heparinus comb. nov., Pedobacter piscium comb. nov., Pedobacter africanus sp. nov. and Pedobacter saltans sp. nov. Proposal of the family Sphingobacteriaceae fam. nov.
}

\author{
P. L. Steyn, ${ }^{1}$ P. Segers, ${ }^{2}$ M. Vancanneyt, ${ }^{2}$ P. Sandra, ${ }^{3}$ K. Kersters ${ }^{2}$ \\ and J. J. Joubert ${ }^{4}$
}

Author for correspondence: P. Segers. Tel: +329 2645115. Fax: + 3292645346.

e-mail: Paul.Segers@rug.ac.be

1 Departement

Mikrobiologie en

Plantpatologie,

Universiteit van Pretoria,

0002 Pretoria, South Africa

2 Laboratorium voor

Microbiologie, Universiteit

Gent, B-9000 Gent,

Belgium

3 Laboratorium voor Organische Scheikunde,

Universiteit Gent, B-9000

Gent, Belgium

4 Departement Geneeskundige Mikrobiologie, Universiteit van Stellenbosch, Posbus 19063, 7505 Tygerberg, South Africa

\begin{abstract}
Sixteen heparinase-producing isolates, related to Sphingobacterium heparinum, were grouped into three major clusters by SDS-PAGE and DNA-rRNA hybridizations. Based on a polyphasic approach, it was shown that isolates of two of these clusters and S. heparinum species belong to a new genus for which the name Pedobacter is proposed. The genus consists of Pedobacter heparinus comb. nov. (formerly Sphingobacterium heparinum), which is the type species, Pedobacter piscium comb. nov. (formerly Sphingobacterium piscium), Pedobacter africanus sp. nov. and Pedobacter saltans sp. nov. and four as-yet-unnamed DNA hybridization groups. All the previously named taxa can be discriminated by phenotypic features, but have strong overall similarities with representatives of the genus Sphingobacterium and the misclassified species [Flexibacter] canadensis. All these organisms constitute a separate rRNA branch in rRNA superfamily $V$ for which the family Sphingobacteriaceae fam. nov. is proposed.
\end{abstract}

Keywords: Pedobacter heparinus comb. nov., Pedobacter piscium comb. nov., Pedobacter africanus sp. nov., Pedobacter saltans sp. nov., Sphingobacteriaceae fam. nov.

\section{INTRODUCTION}

Sphingobacterium heparinum, represented by a single isolate, remained for many years the sole representative of a strictly aerobic Gram-negative, heparinaseproducing bacterium. Joubert (14) succeeded in obtaining heparinase-producing isolates from soil and activated sludge. Sixteen isolates were investigated by SDS-PAGE of whole-cell proteins and found to consist of three discernable groups (26). One group comprising 11 isolates and two subcultures of the type strain of $S$. heparinum were found to cluster into a single group (consisting of two sub-groups Ia and Ib). The second group (II) and a third group (III) contain one and four

Abbreviation: FAME, fatty acid methyl ester. isolates, respectively. Corresponding rRNA groups and sub-groups were found by DNA-rRNA hybridizations $(26,27)$.

The generic status of $S$. heparinum has been discussed repeatedly and the organism has been successively transferred to other genera. The species was first described as Flavobacterium heparinum (20), and was later reclassified in the genus Cytophaga as Cytophaga heparina (2). Reichenbach (21) has already questioned the inclusion of the organism in the genus Cytophaga. More recently the phylogenetic position of $C$. heparina was further elucidated $(7,8,17,18,19,26)$. Based on phenotypic and chemotaxonomic analyses, Takeuchi $\&$ Yokota (28) proposed the transfer of $C$. heparina to the genus Sphingobacterium as $S$. heparinum. The genus Sphingobacterium is part of rRNA superfamily 
Table 1. Strains used, some other strain designations and source of isolation

LMG, Laboratorium voor Microbiologie Gent Culture Collection, University of Gent, Belgium; ATCC, American Type Culture Collection, Rockville, MD, USA; CCUG, Culture Collection of the University of Göteborg, Department of Clinical Bacteriology, University of Göteborg, Sweden; IFO, Institute for Fermentation, Osaka, Yodogawa-ku, Osaka 532, Japan.

\begin{tabular}{|c|c|c|}
\hline Name and LMG no.* & Other designation(s) & Source \\
\hline \multicolumn{3}{|c|}{ Pedobacter heparinus (Ia 1) } \\
\hline LMG $10399^{\mathrm{T}}$ & ATCC $13125^{\mathrm{T}}$, IFO $12017^{\mathrm{T}}$ & Dry soil \\
\hline LMG $10344^{\mathrm{T}} \dagger$ & $\mathrm{AL} \dagger$ & Dry soil \\
\hline \multicolumn{3}{|c|}{ Pedobacter africanus (Ia3) } \\
\hline LMG $10353^{\mathrm{T}}$ & & Belfast, Eastern Transvaal, South Africa; soil \\
\hline LMG 10345 & & Windhoek, Namibia; activated sludge \\
\hline LMG 10346 & & Pretoria, South Africa; soil \\
\hline LMG 10347 & & Western Caprivi, Namibia; soil \\
\hline LMG 10348 & & Pretoria, South Africa; activated sludge \\
\hline LMG 10349 & & Eastern Kavango, Namibia; soil \\
\hline \multicolumn{3}{|l|}{ Pedobacter piscium } \\
\hline LMG $14023^{\mathrm{T}}$ & IFO $14985^{T}$ & - \\
\hline LMG 14024 & IFO 14984 & - \\
\hline \multicolumn{3}{|l|}{ Pedobacter saltans (III) } \\
\hline LMG $10337^{\mathrm{T}}$ & & Iceland; soil \\
\hline LMG 10338 & & Iceland; soil \\
\hline LMG 10340 & & Brussels, Belgium; soil \\
\hline LMG 10341 & & Rüdesheim, Germany; soil \\
\hline \multicolumn{3}{|l|}{ Pedobacter sp. (Ia2) } \\
\hline LMG 9525 & LMG 10350 & Ephesus, Turkey; soil \\
\hline LMG 10343 & & Swartkoppies, Transvaal, South Africa; soil \\
\hline \multicolumn{3}{|l|}{ Pedobacter sp. (Ibl) } \\
\hline LMG 9527 & LMG 10352 & Langkloof, Eastern Cape, South Africa; soil \\
\hline LMG 10354 & & Roodeplaat, Pretoria, South Africa; soil \\
\hline \multicolumn{3}{|l|}{ Pedobacter sp. (Ib2) } \\
\hline LMG 10342 & & Sambyu, Kavango, Namibia; soil \\
\hline \multicolumn{3}{|l|}{ Pedobacter sp. (II) } \\
\hline LMG 10351 & & Amsterdam, The Netherlands; soil \\
\hline \multicolumn{3}{|c|}{ Sphingobacterium spiritivorum } \\
\hline LMG $8347^{\mathrm{T}}$ & CCUG $13224^{\mathrm{T}}$, IFO $14948^{\mathrm{T}}$ & Kansas, USA; intra-uterine device \\
\hline LMG 8348 & CCUG 15910 & - \\
\hline \multicolumn{3}{|c|}{ Sphingobacterium multivorum } \\
\hline LMG $8342^{\mathrm{T}}$ & CCUG $11736^{\mathrm{T}}$, IFO $14947^{\mathrm{T}}$ & Spleen \\
\hline LMG 8354 & CCUG 22177 & Denmark; soil \\
\hline \multicolumn{3}{|c|}{ Sphingobacterium mizutae } \\
\hline LMG $8340 \mathrm{t} 1^{\mathrm{T}}$ & CCUG $15907^{\mathrm{T}}$, IFO $14946^{\mathrm{T}}$ & Ventricular fluid of foetus \\
\hline LMG 8341 & CCUG 15908 & - \\
\hline \multicolumn{3}{|c|}{ Sphingobacterium thalpophilum } \\
\hline LMG $11520^{\mathrm{T}}$ & CCUG $22397^{\mathrm{T}}$, IFO $14963^{\mathrm{T}}$ & Wound swab \\
\hline LMG 11521 & CCUG 22398 & Human abscess \\
\hline \multicolumn{3}{|c|}{ Sphingobacterium faecium } \\
\hline LMG $14022^{\mathrm{T}}$ & IFO $15299^{\mathrm{T}}$ & \\
\hline \multicolumn{3}{|c|}{ [Flavobacterium] yabuuchiae } \\
\hline LMG $11523^{\mathrm{T}}$ & CCUG $26765^{\mathrm{T}}$, IFO $14975^{\mathrm{T}}$ & USA; human sputum \\
\hline \multicolumn{3}{|l|}{ [Flexibacter] canadensis } \\
\hline LMG $8368^{\mathrm{T}}$ & $\operatorname{ATCC} 29591^{\mathrm{T}}$ & Soil \\
\hline
\end{tabular}

* The SDS-PAGE or DNA hybridization sub-group number (26, 27 and this paper) are shown in parentheses.

† Strain LMG $10344^{\mathrm{T}}$ is an independently received subculture (from Dr A. Linker, Salt Lake City, UT, USA) of the type strain. 
$\mathrm{V}$, the so-called Cytophaga-Flavobacterium-Bacteroides group $(1,23,26)$. The confused taxonomy of this large group of bacteria was recently clarified by rRNA similarity studies $(1,7,8,17,18,19)$ and quinone analyses $(5,17,18,28)$. This resulted in the creation of new genera $(18,30)$ and emended descriptions of the genus Flavobacterium, the family Flavobacteriaceae (1) and the genus Cytophaga (18).

This paper reports on the classification of the heparinase-producing isolates by a more detailed phenotypic description and determination of fatty acid content of the obtained clusters and related organisms, together with some additional DNA-rRNA and DNA-DNA hybridizations. Preliminary data have already been presented by Steyn et al. (27). A new genus Pedobacter, encompassing two former Sphingobacterium species, Pedobacter heparinus comb. nov. and Pedobacter piscium comb. nov., and two new species, Pedobacter africanus and Pedobacter saltans, is proposed. These names will be used throughout this paper. Several strains with a separate genotypic position will be classified and can be considered as unnamed genomic species of Pedobacter. We also propose the family Sphingobacteriaceae comprising the newly described organisms, the genus Sphingobacterium and [Flexibacter] canadensis. Square brackets are used to indicate generically misclassified bacteria.

\section{METHODS}

Micro-organisms and growth conditions. Strains studied are listed in Table 1. Information about the bacterial strains, considered in this paper, and growth conditions were given before $(26,27,28,32)$.

Conventional tests. The conventional tests were done according to Cowan (4) or Sonnenwirth (25), unless stated otherwise. The oxidation/fermentation test was done in SIM medium (Merck). Acid and gas production from glucose, lactose and sucrose were determined in Kligler Iron agar (Difco Laboratories). Cytochrome- $c$ oxidase was determined by adding a few drops of tetramethyl- $p$-phenylenediamine solution to a 5-d-old Tryptose agar (Biolab) slant. Lysine deaminase and lysine decarboxylase were determined in Lysine iron agar (Biolab). Utilization of citrate and mannitol was determined on Citrate mannitol agar (Biolab). Urease activity was determined in Urease agar base (Difco) to which $1.5 \%$ agar was added. For the determination of acid production from inositol and arabinose a sugar base consisting of $2 \%$ Bacto peptone (Difco) and $0.5 \% \mathrm{NaCl}$ was used, to which $2.5 \%$ inositol or arabinose was added. Nitrate reduction was determined on Sellers agar (Difco). The medium described by Cowan (1979) was used for the determination of ornithine decarboxylase. The isolates were also tested for their ability to grow on MacConkey agar (Difco). The inoculated tubes were incubated at $25^{\circ} \mathrm{C}$ and read after 7 and $14 \mathrm{~d}$, respectively. Positive and negative controls were included in all tests. Heparinase production was determined by the method of Joubert et al. (13).

Carbon assimilation tests. The API 50CH, 50AO, 50AA (API Systems) galleries were used according to a standardized procedure (15).

API 20E and API ZYM micromethod tests. These tests were done according to the instructions of the manufacturer (API
Systems). A suspension was made of a 3-d-old slant in sterile water, adjusted to give a reading of 5-6 on the MacFarland scale and used for inoculating the galleries. The API 20E galleries were incubated at $25^{\circ} \mathrm{C}$ for $7 \mathrm{~d}$, and the API ZYM galleries at $30^{\circ} \mathrm{C}$ for $4 \mathrm{~h}$.

GC of cellular fatty acids. The methods using the MIS system (Microbial Identification System) have been described previously (27). Fatty acid methyl esters (FAMEs) were separated on an apolar fused silica capillary column coated with a phenyl methyl silicone gum phase (Hewlett-Packard). Under these conditions the fatty acids $16: 1 \omega 7 \mathrm{c}$ and iso15:0(2-OH), two major components of the taxa studied, eluted for most strains as a single peak. To quantify both FAMEs a second analysis was performed on a polar cyanopropyl silicone column (31) where both peaks elute at clearly different retention times.

DNA-rRNA and DNA-DNA hybridizations. DNA-rRNA and DNA-DNA hybridizations were performed as described previously $(26,27)$.

\section{RESULTS}

\section{DNA-rRNA hybridization}

Previous data $(26,27)$ together with results from this study (Table 2), are presented in Fig. 1 as a simplified dendrogram based on the thermal stability of the hybrids $\left[T_{\mathrm{m}(\mathrm{e})}\right.$ values]. The overall groupings are similar to those described previously $(26,27)$. The heparinase-producing bacteria are situated on a separate rRNA branch, the Pedobacter branch, consisting of two sub-branches, the $P$. heparinus sub-branch and the $P$. saltans sub-branch. Several genotypic subgroups and $S$. piscium are situated on the $P$. heparinus sub-branch. Sphingobacterium species and [Flexibacter] canadensis are the nearest relatives to the Pedobacter branch.

\section{DNA-DNA hybridization}

Hybridizations were performed between and within each of the rRNA groups or corresponding protein electrophoretic groups. The results are shown in Table 3 . The $P$. heparinus sub-branch (RNA group $I, 26$ ) is shown to split up into seven genotypic sub-groups. Five of these genomic groups belong to the protein clusters Ia and $\mathrm{Ib}(26)$ : P. heparinus (Ia1), P. africanus (Ia3), and three unnamed Pedobacter genomic species (Ia2, Ib1 and Ib2). Pedobacter strain LMG 10351 (group II) and $P$. piscium, also located on this $P$. heparinus rRNA sub-branch, showed no significant DNA similarity with the former five sub-groups. The protein electrophoretic group III strains $(P$. saltans sub-branch) constitute a separate and homogeneous group.

\section{GC of cellular fatty acids}

Table 4 shows the cellular fatty acid content of the heparinase-producing taxa (sub-groups) and of the Sphingobacterium species. Dominant fatty acids for all strains were: iso-15:0, iso-15:0(2-OH), iso-15:0(3- 
Table 2. DNA base compositions of strains and $T_{m(e)}$ values of DNA-rRNA hybrids

Some data are from references $(23),(26)$ and $(27)$.

\begin{tabular}{|c|c|c|c|c|c|}
\hline \multirow[t]{2}{*}{ Name* } & \multirow[t]{2}{*}{ LMG no. } & \multirow{2}{*}{$\begin{array}{c}G+C \text { content } \\
(\mathrm{mol} \%)\end{array}$} & \multicolumn{3}{|c|}{$T_{\mathrm{m}(\mathrm{e})}$ in ${ }^{\circ} \mathrm{C}$ with ${ }^{3} \mathrm{H}$-labelled $23 \mathrm{~S}$ rRNA of } \\
\hline & & & $\begin{array}{l}\text { P. heparinus } \\
\text { LMG 10339 }\end{array}$ & 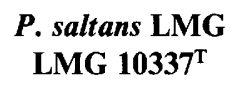 & $\begin{array}{l}\text { S. spiritivorum } \\
\text { LMG 8347 }^{\mathrm{T}}\end{array}$ \\
\hline Pedobacter heparinus (Ia1) & $10339^{\mathrm{T}}$ & $43 \cdot 0$ & $80 \cdot 0$ & $70 \cdot 4$ & $67 \cdot 1$ \\
\hline Pedobacter heparinus (Ial) & $10344^{\mathrm{T}}$ & $42 \cdot 3$ & $80 \cdot 1$ & & \\
\hline Pedobacter sp. (Ia2) & 9525 & $42 \cdot 9$ & $79 \cdot 3$ & & \\
\hline Pedobacter sp. (Ia2) & 10343 & $42 \cdot 3$ & 78.9 & & \\
\hline Pedobacter africanus (Ia3) & $10353^{T}$ & $44 \cdot 2$ & $77 \cdot 8$ & & \\
\hline Pedobacter africanus (Ia3) & 10348 & $44 \cdot 1$ & $78 \cdot 2$ & $70 \cdot 9$ & \\
\hline Pedobacter africanus (Ia3) & 10349 & $43 \cdot 7$ & $77 \cdot 9$ & & \\
\hline Pedobacter sp. (Ib1) & 9527 & $37 \cdot 5$ & $77 \cdot 0$ & $70 \cdot 9$ & $67 \cdot 4$ \\
\hline Pedobacter sp. (Ib1) & 10354 & $37 \cdot 4$ & $76 \cdot 8$ & & $67 \cdot 4$ \\
\hline Pedobacter sp. (Ib2) & 10342 & $39 \cdot 5$ & $77 \cdot 4$ & & \\
\hline Pedobacter piscium & $14023^{\mathrm{T}}$ & $40 \cdot 4$ & $75 \cdot 3$ & $70 \cdot 3$ & $68 \cdot 9$ \\
\hline Pedobacter piscium & 14024 & $41 \cdot 0$ & $75 \cdot 5$ & $70 \cdot 2$ & $69 \cdot 3$ \\
\hline Pedobacter sp. (II) & 10351 & $41 \cdot 2$ & $74 \cdot 2$ & $71 \cdot 6$ & \\
\hline Pedobacter saltans (III) & $10337^{\mathrm{T}}$ & $37 \cdot 0$ & $70 \cdot 9$ & $81 \cdot 2$ & $67 \cdot 6$ \\
\hline Pedobacter saltans (III) & 10338 & $36 \cdot 9$ & $70 \cdot 5$ & $81 \cdot 2$ & \\
\hline Pedobacter saltans (III) & 10341 & $37 \cdot 1$ & $70 \cdot 6$ & $80 \cdot 9$ & \\
\hline Sphingobacterium spiritivorum & $8347^{\mathrm{T}}$ & $39 \cdot 8$ & $69 \cdot 5$ & $68 \cdot 5$ & $77 \cdot 2$ \\
\hline Sphingobacterium spiritivorum & 8348 & $39 \cdot 8$ & & & $76 \cdot 7$ \\
\hline Sphingobacterium multivorum & $8342^{\mathrm{T}}$ & $40 \cdot 5$ & $67 \cdot 4$ & $68 \cdot 7$ & $72 \cdot 6$ \\
\hline Sphingobacterium multivorum & 8354 & $39 \cdot 9$ & & & $73 \cdot 0$ \\
\hline Sphingobacterium mizutae & $8340 \mathrm{t} 1^{\mathrm{T}}$ & $39 \cdot 3$ & $67 \cdot 3$ & $69 \cdot 5$ & $71 \cdot 2$ \\
\hline Sphingobacterium mizutae & 8341 & $40 \cdot 0$ & & & $72 \cdot 3$ \\
\hline Sphingobacterium thalpophilum & $11520^{\mathrm{T}}$ & $44 \cdot 0$ & $65 \cdot 2$ & & $69 \cdot 0$ \\
\hline Sphingobacterium thalpophilum & 11521 & $44 \cdot 2$ & & & $68 \cdot 2$ \\
\hline Sphingobacterium faecium & $14022^{\mathrm{T}}$ & $37 \cdot 3$ & $67 \cdot 3$ & $69 \cdot 0$ & $73 \cdot 5$ \\
\hline [Flavobacterium] yabuuchiae & $11523^{\mathrm{T}}$ & $38 \cdot 1$ & & & $76 \cdot 6$ \\
\hline [Flexibacter] canadensis & $8368^{\mathrm{T}}$ & 38.4 & $67 \cdot 9$ & & \\
\hline
\end{tabular}

* The SDS-PAGE or DNA hybridization sub-group numbers are shown in parentheses (see Table 1).

$\mathrm{OH}), 16: 0,16: 1 \omega 7 \mathrm{c}$ and iso-17:0(3-OH). As discussed below, only minor qualitative differences among the different genera and species are found. Characteristic for all representatives of the newly proposed family Sphingobacteriaceae is the presence of significant amounts of the fatty acids iso-15:0(2-OH) and 16: $1 \omega 7 \mathrm{c}$ (both comprised into summed feature 4, MIS version 3.9). As explained above, using the MIS GC conditions both FAMEs have very similar retention times and in several cases elute as a single peak. Using a more polar chromatographic system, we proved that iso-15:0(2-OH) and 16:1 $107 \mathrm{c}$ occur in all of the taxa investigated. Our data confirmed that presented by Yabuuchi \& Moss (33), Yabuuchi et al. (32), Dees et al. (5), and Takeuchi \& Yokota (28).

\section{Phenotypic features}

The results of an extensive phenotypic analysis and sensitivity study to antibiotics, with descriptive and discriminative information, are presented in Tables 5 and 6. [Flavobacterium] yabuuchiae and [Flexibacter] canadensis were not tested. All strains studied produce on most agar media a yellow or creamy white nonfluorescent pigment, and they produce catalase, oxidase, phosphatase, esterase lipase (C8), leucine arylamidase, $\alpha$-glucosidase and $N$-acetyl- $\beta$-glucosaminidase. Of the 49 carbohydrates tested (Table 5), all strains assimilate the carbohydrates D-glucose, Dmannose and amygdalin, and 11 of these compounds are not utilized. Very few organic acids are utilized. Several Pedobacter strains and one Sphingobacterium mizutae strain can utilize pyruvate. Of the 49 amino acids and amines tested, glucosamine is utilized by all strains, whereas 12 of these substrates are utilized by some strains (Table 5).

\section{DISCUSSION}

\section{Proposal of Pedobacter gen. nov.}

The genus Sphingobacterium was created by Yabuuchi et al. (32) to contain two former Flavobacterium species $(10,11)$, Sphingobacterium spiritivorum and Sphingo- 
Table 3. Levels of DNA relatedness expressed as percentage DNA binding among the Pedobacter taxa studied

Taxa are grouped by SDS-PAGE or DNA hybridization sub-group numbers (see Table 1).

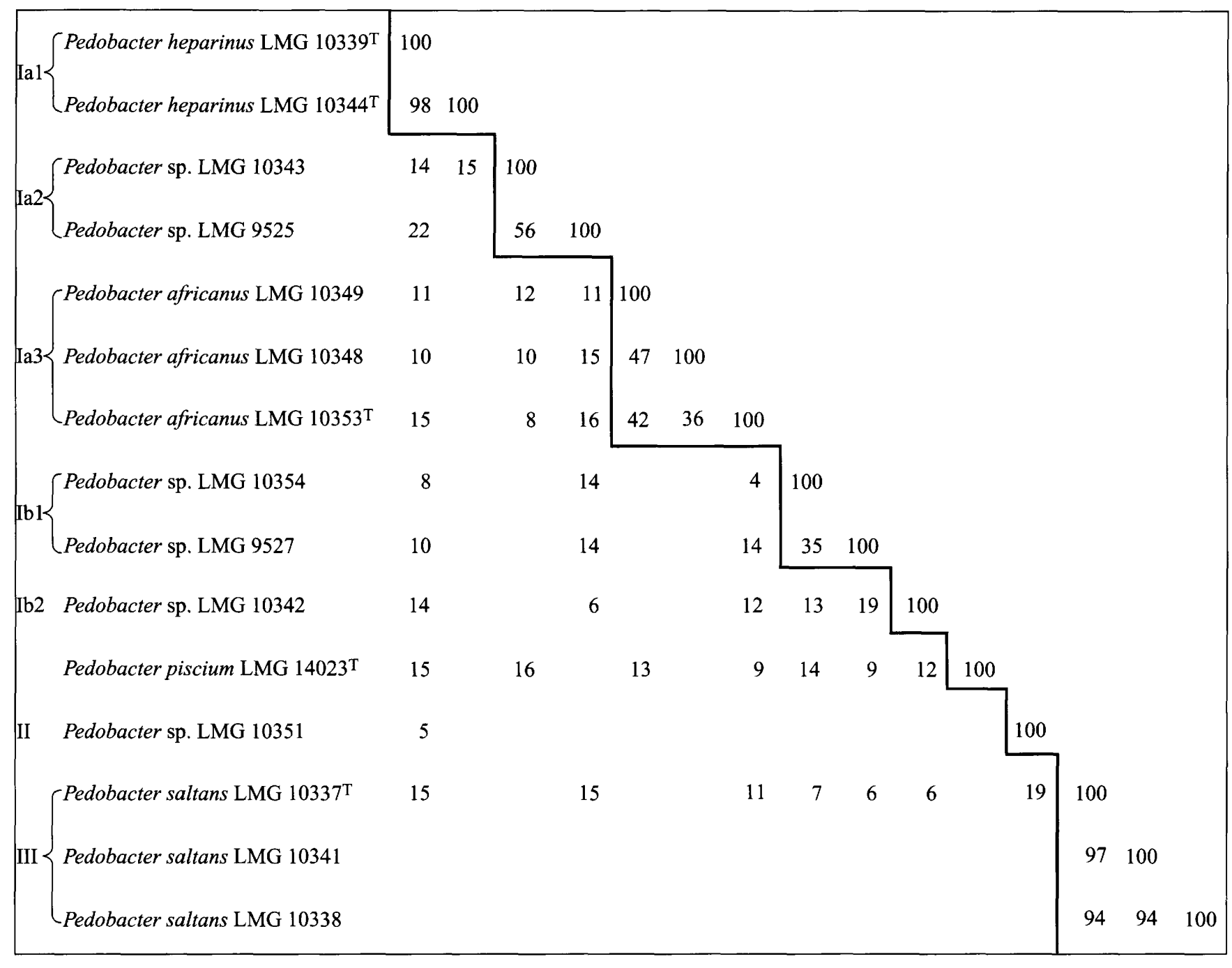

bacterium multivorum, and $S$. mizutae. Takeuchi \& Yokota (28) extended the genus with three species, Sphingobacterium piscium, Sphingobacterium faecium and Sphingobacterium thalpophilum (previously classified as Flavobacterium thalpophilum). The latter authors demonstrated the synonymy among [Flavobacterium] yabuuchiae and S. spiritivorum. They also transferred $C$. heparina to the genus Sphingobacterium because of homogeneity in morphological, physiological and chemotaxonomic characteristics. DNArRNA hybridization results (Fig. 1) supported most of these data but clearly demonstrated that the genus was phylogenetically too broad. Large $T_{\mathrm{m}(\mathrm{e})}$ differences of $8-12^{\circ} \mathrm{C} T_{\mathrm{m}(\mathrm{e})}$ (depending on the branch) are found, whereas it has been demonstrated that within wellcharacterized genera differences in $T_{\mathrm{m}(\mathrm{e})}$ values most often range from 4 to $7^{\circ} \mathrm{C}$ (6). Our rRNA cistron similarity studies revealed that the Sphingobacterium branch, containing strains of $S$. spiritivorum, S. multivorum, S. mizutae, S. faecium and S. thalpophilum, was linked to the heparinase-producing bacteria at a mean $T_{\text {m(e) }}$ of about $68^{\circ} \mathrm{C}$ (Fig. 1). These data justify the creation of the new genus Pedobacter for the heparinase-producing isolates. The Pedobacter branch splits into two sub-branches at $T_{\mathrm{m}(\mathrm{e})}=70.9^{\circ} \mathrm{C}$. Although the Pedobacter saltans sub-branch can be considered to constitute a separate genus based on the large $T_{\mathrm{m}(\mathrm{e})}$ difference, it is provisionally classified in the genus Pedobacter because of the limited number of strains available (four), and the lack of differentiating phenotypic features. Furthermore, we propose to reclassify $S$. heparinum and $S$. piscium, with newly isolated heparinase-producing taxa, in the genus Pedobacter. Sphingobacterium still remains genotypically a rather heterogeneous genus $\left[T_{\mathrm{m}(\mathrm{e})}\right.$ span of $\left.8^{\circ} \mathrm{C}\right]$, with $S$. thalpophilum as the most remote species; however, a lack of distinctive features (Table $5 ; 28$ ) of its members justifies for the moment the current classification.

Sphingobacterium antarcticus was not included in this study because no subcultures were available from any 
Table 4. Mean relative fatty acid composition of Pedobacter and Sphingobacterium taxa

Standard deviations are shown in parentheses; TR, trace $(<1.0 \%) ;-$, not detected. Abbreviations: Fa., Flavobacterium; $F$., Flexibacter; P., Pedobacter; S., Sphingobacterium; ECL, equivalent chain length.

\begin{tabular}{|c|c|c|c|c|c|c|c|c|c|}
\hline Name* & $\begin{array}{c}\text { ECL } \\
13.566\end{array}$ & $14: 0$ & $15: 0$ & $15: 1 \omega 6 c$ & $\begin{array}{l}\text { iso- } \\
15: 0\end{array}$ & $\begin{array}{c}\text { anteiso- } \\
15: 0\end{array}$ & $\begin{array}{c}\text { iso- } \\
15: 0(2-\mathrm{OH})\end{array}$ & $\begin{array}{c}\text { iso- } \\
15:(3-\mathrm{OH})\end{array}$ & $16: 0$ \\
\hline P. heparinus (Ia1) & $5 \cdot 0(2 \cdot 9)$ & ) $1 \cdot 1(0 \cdot 1)$ & ) $1 \cdot 1(0 \cdot 1)$ & - & $28 \cdot 2(3 \cdot 7)$ & TR & $10 \cdot 4(0 \cdot 3)$ & $2 \cdot 5(0 \cdot 1)$ & $3 \cdot 0(0 \cdot 4)$ \\
\hline P. africanus (Ia3) & $2 \cdot 6(0 \cdot 5)$ & $1.5(0.4)$ & TR & TR & $26 \cdot 6(2 \cdot 6)$ & TR & $10 \cdot 4(1 \cdot 2)$ & $2 \cdot 1(0 \cdot 8)$ & $3 \cdot 8(1 \cdot 3)$ \\
\hline P. piscium & TR & $1 \cdot 3(0 \cdot 1)$ & - & - & $26 \cdot 2(0 \cdot 3)$ & $2 \cdot 6(0 \cdot 5)$ & $10 \cdot 7(0.5)$ & $2 \cdot 5(0 \cdot 4)$ & $3 \cdot 3(0 \cdot 6)$ \\
\hline P. saltans (III) & $1 \cdot 1(0 \cdot 2)$ & TR & $1.4(0 \cdot 3)$ & $1.4(0.2)$ & $31 \cdot 4(2 \cdot 6)$ & $2 \cdot 9(0 \cdot 4)$ & $8.9(1.6)$ & $2 \cdot 8(0 \cdot 3)$ & $4 \cdot 0(0 \cdot 7)$ \\
\hline Pedobacter sp. (Ia2) & $1 \cdot 6(0 \cdot 3)$ & $1.2(0 \cdot 3)$ & TR & TR & $27 \cdot 2(3 \cdot 5)$ & TR & $9 \cdot 5(1 \cdot 2)$ & $3 \cdot 1(0 \cdot 1)$ & $2 \cdot 2(1 \cdot 1)$ \\
\hline Pedobacter sp. (Ibl) & $2 \cdot 1(0 \cdot 6)$ & ) $1.0(0 \cdot 1)$ & TR & TR & $25 \cdot 4(6 \cdot 7)$ & TR & $9.9(1.2)$ & $2 \cdot 5(0 \cdot 3)$ & $3 \cdot 3(2 \cdot 8)$ \\
\hline Pedobacter sp. (Ib2) & $1 \cdot 7$ & $1 \cdot 6$ & - & - & 28.4 & 1.5 & $7 \cdot 1$ & $2 \cdot 4$ & $3 \cdot 8$ \\
\hline Pedobacter sp. (II) & $2 \cdot 0$ & TR & $1 \cdot 4$ & TR & $38 \cdot 3$ & $1 \cdot 3$ & $15 \cdot 4$ & $2 \cdot 4$ & $1 \cdot 1$ \\
\hline S. faecium & TR & TR & - & - & $24 \cdot 6$ & TR & 15.9 & $3 \cdot 7$ & $4 \cdot 5$ \\
\hline S. mizutae & $1 \cdot 3(0 \cdot 7)$ & TR & - & - & $30 \cdot 0(6 \cdot 2)$ & TR & $25 \cdot 6(8 \cdot 2)$ & $3 \cdot 0(1 \cdot 1)$ & TR \\
\hline S. multivorum & - & $2 \cdot 7(1.6)$ & - & - & $22 \cdot 2(3 \cdot 6)$ & - & $17 \cdot 4(0.9)$ & $3 \cdot 2(1 \cdot 1)$ & $7 \cdot 8(2 \cdot 8)$ \\
\hline S. spiritivorum & TR & $1.0(0 \cdot 4)$ & - & - & $30 \cdot 1(2 \cdot 0)$ & TR & $21.5(0.3)$ & $2 \cdot 2(0 \cdot 3)$ & $3 \cdot 5(0 \cdot 1)$ \\
\hline S. thalpophilum & $1.4(0.0)$ & $3 \cdot 2(0 \cdot 2)$ & - & - & $17 \cdot 7(0 \cdot 1)$ & - & $24 \cdot 6(1 \cdot 3)$ & $4 \cdot 3(0 \cdot 2)$ & $6 \cdot 0(0 \cdot 9)$ \\
\hline [Fa.] yabuuchiae & TR & TR & - & - & $30 \cdot 4$ & $2 \cdot 3$ & $20 \cdot 6$ & $2 \cdot 2$ & $3 \cdot 2$ \\
\hline \multirow[t]{2}{*}[F.]{ canadensis $\dagger$} & TR & TR & $2 \cdot 2$ & 1.8 & $35 \cdot 7$ & 4.9 & $\mathrm{ND} \ddagger$ & $3 \cdot 5$ & $2 \cdot 6$ \\
\hline & $16: 1 \omega 5 \mathrm{c}$ & $16: 1 \omega 7 \mathrm{c}$ & $\begin{array}{c}16: 010 \\
\text { methyl }\end{array}$ & $\begin{array}{c}16: 0 \\
(2-\mathrm{OH})\end{array}$ & $\begin{array}{c}16: 0 \\
(3-O H)\end{array}$ & $\begin{array}{c}\text { ECL } \\
16.580\end{array}$ & $\begin{array}{c}\text { iso- } \\
17: 1 \omega 9 \mathrm{c}\end{array}$ & $\begin{array}{l}\text { anteiso- } \\
17: 1 \omega 9 \mathrm{c}\end{array}$ & $\begin{array}{c}\text { iso- } \\
17: 0(3-O H)\end{array}$ \\
\hline P. heparinus (Ia 1) & $1.4(0.2)$ & $20 \cdot 2(0 \cdot 5)$ & - & - & $1 \cdot 5(0 \cdot 1)$ & $1 \cdot 0(0 \cdot 1)$ & $6 \cdot 3(0 \cdot 6)$ & - & $15 \cdot 2(0 \cdot 8)$ \\
\hline P. africanus (Ia3) & $2 \cdot 1(0 \cdot 3) 2$ & $23 \cdot 7(3 \cdot 5)$ & - & TR & $3 \cdot 1(0 \cdot 7)$ & $1 \cdot 0(0 \cdot 2)$ & $4.4(1.2)$ & - & $14 \cdot 7(2 \cdot 2)$ \\
\hline P. piscium & $3.5(0.4)$ & $31.4(1.9)$ & - & - & $4 \cdot 5(0 \cdot 7)$ & TR & $1 \cdot 6(0 \cdot 2)$ & $1 \cdot 2(0 \cdot 3)$ & $9 \cdot 2(1 \cdot 4)$ \\
\hline P. saltans (III) & TR & $19 \cdot 6(1 \cdot 5)$ & - & - & TR & $1 \cdot 2(0 \cdot 1)$ & $6.6(1.4)$ & - & $12 \cdot 7(0.6)$ \\
\hline Pedobacter sp. (Ia2) & $4.0(1.9) 2$ & $24 \cdot 5(6 \cdot 2)$ & - & - & $1 \cdot 2(0 \cdot 7)$ & TR & $6 \cdot 0(2 \cdot 7)$ & - & $15 \cdot 3(0 \cdot 5)$ \\
\hline Pedobacter sp. (Ib1) & $4 \cdot 5(3 \cdot 0) 2$ & $26 \cdot 1(4 \cdot 2)$ & - & - & $1 \cdot 8(0 \cdot 6)$ & TR & $4 \cdot 5(2 \cdot 8)$ & - & $13 \cdot 2(0 \cdot 9)$ \\
\hline Pedobacter sp. (Ib2) & $3 \cdot 5$ & $30 \cdot 1$ & - & - & $1 \cdot 6$ & TR & 3.8 & TR & $11 \cdot 3$ \\
\hline Pedobacter sp. (II) & 1.6 & $14 \cdot 2$ & - & - & $3 \cdot 0$ & $1 \cdot 1$ & $2 \cdot 2$ & - & $12 \cdot 4$ \\
\hline S. faecium & 1.5 & $32 \cdot 2$ & 1.4 & - & $2 \cdot 1$ & TR & - & - & $10 \cdot 0$ \\
\hline S. mizutae & TR & $9 \cdot 5(2 \cdot 4)$ & - & - & $\mathrm{TR}$ & TR & $3 \cdot 7(0 \cdot 2)$ & - & $22 \cdot 1(0 \cdot 6)$ \\
\hline S. multivorum & - & $31 \cdot 6(1 \cdot 2)$ & - & TR & $5 \cdot 3(1.4)$ & TR & TR & - & $7 \cdot 1(2 \cdot 2)$ \\
\hline S. spiritivorum & TR & $21 \cdot 1(1 \cdot 5)$ & - & - & $2 \cdot 7(0 \cdot 1)$ & TR & $1 \cdot 7(0 \cdot 3)$ & - & $12.5(0.8)$ \\
\hline S. thalpophilum & - & $23.2(0.8)$ & - & $3 \cdot 2(0.1)$ & $6 \cdot 3(0 \cdot 3)$ & - & - & - & $10.0(0.1)$ \\
\hline [Fa.] yabuuchiae & TR & $19 \cdot 1$ & - & - & 1.8 & TR & $2 \cdot 0$ & - & $13 \cdot 1$ \\
\hline$[F$.$] canadensis \dagger$ & $2 \cdot 7$ & $\mathrm{ND} t$ & - & - & $2 \cdot 5$ & $1 \cdot 1$ & $2 \cdot 5$ & - & $17 \cdot 7$ \\
\hline
\end{tabular}

* SDS-PAGE or DNA hybridization sub-group numbers are shown in parentheses (see Table 1). All strains in Table 1 were studied. $\dagger$ Contains also $1.5 \% 17: 1 \omega 6 \mathrm{c}$ and $2.8 \%$ of summed feature 5 (iso-17:1 I or anteiso-17:1 B, or both).

$¥$ The fatty acids iso-15:0(2-OH) and $16: 1 \omega 7 \mathrm{c}$ were not separated using the MIS system. A peak counting for $14 \cdot 3 \%$ of the total fatty acid content eluted with that retention time. The relative amounts of both FAMEs were not determined.

culture collection. Since the species is psychrotrophic and differs in many physiological characteristics (24), it can be considered as not belonging to the newly proposed Pedobacter taxa and may be distantly related to other Sphingobacterium species (28).

Candidatus comitans, a bacterium living in co-culture with the myxobacterium Chondromyces crocatus was recently described as a possible new Sphingobacterium species (12). Its unique ecological niche and its virtual inability to grow as a pure culture are acceptable grounds to postulate that this bacterium is different from the proposed Pedobacter species.
[Flexibacter] canadensis, a misclassified Flexibacter species containing only one strain, is located at the borderline of the Sphingobacterium and Pedobacter branches. Recovery of more isolates and a further study will be decisive for the creation of a new genus for this species. rRNA sequence analyses revealed an analogous phylogenetic relatedness between $P$. heparinus, the genus Sphingobacterium and [Flexibacter] canadensis $(7,8,16,17,18)$. Phylogenetic trees from the latter studies and from this study demonstrate that $P$. heparinus is distantly related to [Flexibacter] canadensis and to the Sphingobacterium species. 
Although many common biochemical and chemotaxonomical features are found for the genera Sphingobacterium and Pedobacter, a few of them differentiate each genera and several more can be used for species differentiation (18; Tables 4, 5 and 6). Pedobacter can be differentiated from Sphingobacterium by the ability to produce heparinase (except $P$. piscium), absence of urease activity, inability of most strains to produce acid from melibiose and the inability to assimilate D-melezitose. Furthermore, all heparinaseproducing strains (not $P$. piscium) do not show trypsin activity and only Sphingobacterium species, except $S$. mizutae, demonstrate $\alpha$-fucosidase activity. Sphingobacterium species are also differentiated by greater amounts of iso-15:0(2-OH) and Pedobacter taxa, except $P$. saltans, possess significantly higher amounts of $16: 1 \omega 5 \mathrm{c}$. We conclude that when considering the differences in $T_{\mathrm{m}(\mathrm{e})}$ values of DNA-rRNA hybridizations as well as the above-mentioned phenotypical differences, there are sufficient grounds for the description of a new genus, Pedobacter. Thus far, all heparinase-producing bacteria were isolated from soil or activated sludge, whereas most Sphingobacterium strains are of clinical origin.

\section{Proposal of new species}

As reported before $(26,27)$, the heparinase-producing bacteria were classified by SDS-PAGE, DNA-rRNA hybridization, $\mathrm{G}+\mathrm{C}$ content and phenotypical analysis into three main clusters. Cluster I was further subdivided into two sub-groups Ia and $\mathrm{Ib}$. Table 3 demonstrates that these sub-groups contain respectively three (Ia1, Ia2 and Ia3) and two (Ib1 and Ib2) DNA hybridization groups. DNA hybridization group Ial, encompassing solely the type strain of $S$. heparinum, is reclassified as $P$. heparinus. Six new isolates of DNA hybridization group Ia3 are classified as a new species named $P$. africanus. Because the other taxa, Ia2, Ib1 and Ib2, do not contain a set of independently isolated strains no new species names are proposed for these DNA hybridization groups. They can be considered as-yet-unnamed genospecies of the genus Pedobacter. Isolation of more strains may lead to the description of new species names for these sub-groups. Cluster II is shown to be more related to $P$. heparinus $\left[T_{\mathrm{m}(\mathrm{e})}=74 \cdot 2^{\circ} \mathrm{C}\right]$ than to $P$. saltans (cluster III) $\left[T_{\mathrm{m}(\mathrm{e})}\right.$ $\left.=71.6{ }^{\circ} \mathrm{C}\right]$. Due to the presence of a single isolate in cluster II, the strain is not named and is described as Pedobacter sp. For cluster III, a very homogeneous (DNA hybridization levels of $94 \%$ and higher) and separate DNA hybridization group, the species name $P$. saltans is proposed.

Although all species and genospecies are phenotypically highly similar, they can be differentiated by a combination of tests (Tables 5 and 6). Also, Steyn et al. (27) performed a cluster analysis of carbon assimilation tests and found a comparable clustering of the DNA hybridization sub-groups. Only the single strain (LMG 10342) of sub-group Ib2 grouped among strains of $P$. africanus (sub-group Ia3). Data presented in Table 5 demonstrate that some phenotypic features differentiate the latter two taxa. $P$. heparinus can be differentiated from most other taxa of the genus by its ability to grow on sorbitol and L-fucose and its lack of valine arylamidase. $P$. africanus can be discriminated by its ability to assimilate several amino acids (Table 5). P. piscium is the only Pedobacter species containing trypsin. $P$. saltans can phenotypically be differentiated from most Pedobacter strains by its inability to assimilate D-cellobiose and the ability to utilize glycerol. Most $P$. saltans strains have a peculiar gliding, dancing motility. Strain LMG 10351 (cluster II) is metabolically more inert. Only six of 98 compounds of API $50 \mathrm{CH}$ and $50 \mathrm{AO}$ are assimilated, whereas several amino acids (API 50AA) are utilized. Within Pedobacter, only the fatty acid composition of strain LMG 10351 (cluster II) is clearly different from the other species, having a greater amount of iso-15:0 and less $16: 1 \omega 7 \mathrm{c}$. Small differences in the amounts of $15: 1 \omega 6 \mathrm{c}$ and 16:0(3-OH) are demonstrated for $P$. saltans (Table 3). $P$. piscium contains a measurable amount of anteiso-17:1 $\omega 9 \mathrm{c}$. Phenotypic differences among species of the genus Sphingobacterium are presented in Table 5 and summarized by Takeuchi \& Yokota (28). $S$. mizutae and $S$. thalpophilum are characterized by different amounts of the fatty acids $16: 1 \omega 7 \mathrm{c}$ and $16: 0(2-\mathrm{OH})$, respectively.

\section{Proposal of Sphingobacteriaceae fam. nov.}

Gherna \& Woese (8) classified C. heparina, Sphingobacterium species and [Flexibacter] canadensis in the 'Sphingobacter' rRNA sub-group of the 'Flavobacter-Bacteroides' phylum. DNA-rRNA hybridization data demonstrated an analogous separate and homogeneous position of these taxa within superfamily V (Cytophaga-Flavobacterium-Bacteroides group) (1, 23; Fig. 1). Differences in $T_{\mathrm{m}(\mathrm{e})}$ values of up to $12^{\circ} \mathrm{C}$ are found within bacterial families $(6,29)$. Based on a similar range in $T_{\mathrm{m}(\mathrm{e})}$ of $13^{\circ} \mathrm{C}$ as well as other common features, we propose here the bacterial family Sphingobacteriaceae. Taxa within the family are the genera Sphingobacterium and Pedobacter, [Flexibacter] canadensis and Candidatus comitans. Differentiating features from other 'flavobacteria', e.g. the emended family Flavobacteriaceae (1), are the possession of sphingolipids, the presence of the MK-7 quinone system, a higher mean $\mathrm{G}+\mathrm{C}$ content and a unique fatty acid content (iso-15:0, iso-15:0(2-OH), iso- $15: 0(3-\mathrm{OH}), 16: 0,16: 1 \omega 7 \mathrm{c}, 16: 0(3-\mathrm{OH})$ and iso$17: 0(3-\mathrm{OH})$ as the most important components).

\section{Description of Pedobacter gen. nov.}

Pedobacter (Pe'do.bac.ter. Gr. n. pedon soil; M.L. n. bacter from the Gr. n. baktron rod or staff; M.L. masc. n. Pedobacter rod or staff from soil).

The description below is based on data from this study, as well as on previous descriptions. Most strains are 


\section{Table 5. Differentiating biochemical features of the Pedobacter and Sphingobacterium taxa studied}

For the taxa, the name, SDS-PAGE or DNA hybridization sub-group number, and LMG number or number of strains investigated (in parentheses) is given. + , Positive; - , negative; $v$, variable; the number of strains positive for the respective feature is shown in parentheses; ND, not determined. All strains are positive for the following features: aerobic growth, production of a yellow or creamy white pigment on nutrient agar, aesculin hydrolysis, presence of catalase, oxidase, acid and alkaline phosphatases, esterase lipase (C8), leucine arylamidase, $\alpha$-glucosidase, $\beta$-galactosidase and $N$-acetyl- $\beta$-glucosaminidase; assimilation of (API 150) D-glucose, D-mannose, amygdalin and glucosamine. Additionally, all Pedobacter strains (P. piscium and Sphingobacterium strains not tested) contain lysine decarboxylase, phosphoamidase; they produce acetoin from sodium pyruvate and degrade chondroitin sulfate. All strains are negative for the following features: Gram stain, motility, sporulation, indole production, acid production from inositol and adonitol; assimilation of (API 150) erythritol, L-xylose, methyl xyloside, L-sorbose, dulcitol, inositol, xylitol, D-tagatose, D-fucose, L-arabitol, gluconate, acetate, propionate, butyrate, iso-butyrate, n-valerate, isovalerate, n-vaproate, heptanoate, caprylate, pelargonate, caprate, oxalate, malonate, maleate, glutarate, adipate, pimelate, suberate, azelate, sebacate, glycolate, DL-lactate, DL-glycerate, DL-3-hydroxybutyrate, D-malate, D-tartrate, L-tartrate, mesotartrate, laevulinate, 2-oxoglutarate, citraconate, itaconate, mesaconate, aconitate, phenylacetate, benzoate, $o$-hydroxybenzoate, $m$-hydroxybenzoate, D-mandelate, L-mandelate, phthalate, iso-phthalate, terephthalate, glycine, D- $\alpha$-alanine, L- $\alpha$-alanine, Lleucine, L-isoleucine, L-norleucine, L-valine, DL-norvaline, DL-2-aminobutyrate, L-cysteine, L-methionine, L-phenylalanine, Dtryptophan, L-tryptophan, trigonelline, L-citrulline, DL-kynurenine, betaine, $\beta$-alanine, DL-3-aminobutyrate, DL-4-aminobutyrate, DL-5-aminovalerate, 2-aminobenzoate, 3-aminobenzoate, 4-aminobenzoate, urea, acetamide, sarcosine, ethylamine, butylamine, amylamine, ethanolamine, benzylamine, diaminobutane, spermine, histamine and tryptamine. Additionally, all Pedobacter strains ( $P$. piscium and Sphingobacterium strains not tested) do not contain lysine deaminase, arginine dihydrolase, phenylalanine deaminase and tryptophan deaminase; they do not produce $\mathrm{H}_{2} \mathrm{~S}$ from thiosulfate and do not grow on MacConkey agar.

\begin{tabular}{|c|c|c|c|c|c|c|c|c|c|c|c|c|c|}
\hline \multirow[t]{2}{*}{ Feature } & \multicolumn{13}{|c|}{ Taxon } \\
\hline & $\begin{array}{c}P . \\
\text { heparinus } \\
\text { Ia1 (2) }\end{array}$ & $\begin{array}{c}P . \\
\text { africanus } \\
\operatorname{Ia3}(6)\end{array}$ & $\begin{array}{c}P . \\
\text { piscium } \\
(2)\end{array}$ & $\begin{array}{c}P . \\
\text { saltans } \\
\text { III (4) }\end{array}$ & $\begin{array}{l}\text { Pedobacter } \\
\text { sp. Ia2 } \\
\text { (2) }\end{array}$ & $\begin{array}{l}\text { Pedobacter } \\
\text { sp. Ib1 } \\
\text { (2) }\end{array}$ & $\begin{array}{l}\text { Pedobacter } \\
\text { sp. Ib2 } \\
\text { LMG } \\
10342\end{array}$ & $\begin{array}{c}\text { Pedobacter } \\
\text { sp. II } \\
\text { LMG } \\
10351\end{array}$ & $\begin{array}{c}S . \\
\text { spiritivorum } \\
(2)\end{array}$ & $\begin{array}{c}S . \\
\text { multivorum } \\
\text { (2) }\end{array}$ & $\begin{array}{c}S . \\
\text { mizutae } \\
\text { (2) }\end{array}$ & $\begin{array}{c}S . \\
\text { thalpophilum } \\
\text { (2) }\end{array}$ & $\begin{array}{c}S . \\
\text { faecium } \\
(1)\end{array}$ \\
\hline Growth at $37^{\circ} \mathrm{C}$ &,$-+^{*}$ & $v(1)$ & $-*$ & $v(3)$ & - & - & - & + & $+^{*}$ & $+^{*}$ & $+^{*}$ & $+^{*}$ & $+^{*}$ \\
\hline Nitrate reduction &,$--^{*}$ & - & $-*$ & - & - & - & - & - & $-{ }^{*}$ & $-{ }^{*}$ & $-^{*}$ & $+^{*}$ & $-{ }^{*}$ \\
\hline Gelatin hydrolysis &,$--^{*}$ & $\mathrm{v}(1)$ & $-^{*}$ & - & - & - & - & ND & $-*$ & $\mathrm{v}^{*}$ & $-{ }^{*}$ & $-^{*}$ & $-{ }^{*}$ \\
\hline Urease &,$--^{*}$ & - & $-^{*}$ & - & - & - & - & - & $t^{*}$ & $t^{*}$ & $+^{*}$ & $+^{*}$ & $+^{*}$ \\
\hline Heparinase & + & + & - & + & + & + & + & + & - & - & - & - & - \\
\hline DNase &,$-+*$ & - & - & - & - & - & - & - & $+^{*}$ & $+^{*}$ & $+^{*}$ & $-{ }^{*}$ & $+^{*}$ \\
\hline \multicolumn{14}{|l|}{ Acid production from: } \\
\hline Sucrose &,$-+^{*}$ & - & $+^{*}$ & - & - & - & - & - & $+^{*}$ & $+^{*}$ & $+^{*}$ & $+^{*}$ & $+^{*}$ \\
\hline Sorbitol &,$-+^{*}$ & - & $-*$ & - & - & - & - & - & $-^{*}$ & $-*$ & $-*$ & $-{ }^{*}$ & $-^{*}$ \\
\hline Melibiose &,$--^{*}$ & - & $\mathrm{v}^{*}$ & - & - & - & + & - & $+^{*}$ & $+^{*}$ & $+^{*}$ & $+^{*}$ & $t^{*}$ \\
\hline Mannitol &,$--^{*}$ & - & $\mathrm{V}^{*}$ & - & - & - & - & - & $+^{*}$ & $-*$ & $-{ }^{*}$ & $-*$ & $-*$ \\
\hline Glucose & $\mathrm{v},+^{*}$ & $v(1)$ & $+^{*}$ & $v(2)$ & $\mathrm{v}$ & $\mathrm{v}$ & - & - & $+^{*}$ & $t^{*}$ & $+^{*}$ & $+^{*}$ & $+^{*}$ \\
\hline Lactose &,$-+^{*}$ & - & $+^{*}$ & - & - & $v$ & - & - & $t^{*}$ & $+^{*}$ & $+^{*}$ & $+^{*}$ & $t^{*}$ \\
\hline L-Arabinose & $\mathrm{v},+^{*}$ & $v(2)$ & $\mathrm{v}^{*}$ & $v(3)$ & $\mathrm{v}$ & $\mathrm{v}$ & - & - & -** & $+^{*}$ & $+^{*}$ & $+^{*}$ & $+^{*}$ \\
\hline Rhamnose &,$--{ }^{*}$ & - & $-^{*}$ & - & - & - & - & - & $-*$ & $\mathrm{v}^{*}$ & $-*$ & $+^{*}$ & $-*$ \\
\hline \multicolumn{14}{|c|}{ Enzyme activities (API ZYM): } \\
\hline Esterase &,$-+*$ & - & $+^{*}$ & - & - & - & - & - & $t^{*}$ & $+^{*}$ & $+^{*}$ & $+^{*}$ & $+^{*}$ \\
\hline Lipase $(\mathrm{Cl} 14)$ &,,$-- *$ & - & $\mathrm{v}^{*}-$ & - & - & - & & - & $+^{*}$ & $\mathrm{v}^{*}$ & $+^{*}$ & $-*$ & $\mathrm{v}^{*}$ \\
\hline Valine arylamidase &,$--*$ & $v(4)$ & $+^{*}$ & $v(1)$ & $\mathrm{v}$ & + & + & + & $+^{*}$ & $+^{*}$ & $+^{*}$ & $+^{*}$ & $+^{*}$ \\
\hline Cystine arylamidase &,$-+*$ & - & $+^{*}$ & - & - & - & - & - & $+^{*}$ & $+^{*}$ & $+^{*}$ & $+^{*}$ & $+^{*}$ \\
\hline Trypsin &,$--^{*}$ & - & $+^{*}$ & - & - & - & - & - & $t^{*}$ & $+^{*}$ & $+^{*}$ & $+^{*}$ & $-*$ \\
\hline Chymotrypsin &,$-+*$ & - & $+^{*}$ & - & - & - & - & - & $+^{*}$ & $+^{*}$ & $+^{*}$ & $+^{*}$ & $+^{*}$ \\
\hline$\alpha$-Galactosidase &,$-+*$ & - & $+*$ & - & - & - & - & - & $+^{*}$ & $+^{*}$ & $-*$ & $+^{*}$ & $+^{*}$ \\
\hline$\beta$-Glucuronidase &,$--*$ & - & $\mathrm{v}^{*}$ & $v(1)$ & - & - & - & - & $+^{*}$ & $\mathrm{v}^{*}$ & $-{ }^{*}$ & $+^{*}$ & $\mathrm{v}^{*}$ \\
\hline$\beta$-Glucosidase &,$-+^{*}$ & $v(2)$ & $t^{*}$ & + & $\mathrm{v}$ & + & + & - & $+^{*}$ & $+^{*}$ & $+^{*}$ & $+^{*}$ & $+^{*}$ \\
\hline$\alpha$-Mannosidase &,$-+*$ & $\mathrm{v}(1)$ & $+^{*}$ & - & - & - & + & - & $+*$ & $+*$ & $+^{*}$ & $+^{*}$ & $+^{*}$ \\
\hline$\alpha$-Fucosidase &,$--^{*}$ & - & $-^{*}$ & - & - & - & - & - & $+^{*}$ & $+^{*}$ & $-*$ & $+^{*}$ & $v^{*}$ \\
\hline \multicolumn{14}{|c|}{ Assimilation of (API 50CH, 50AO, 50 AA): } \\
\hline Glycerol & - & - & - & + & - & $v$ & + & - & $\mathrm{v}$ & - & - & + & + \\
\hline D-Arabinose & - & $\mathrm{v}(2)$ & - & $v(3)$ & $\mathrm{v}$ & + & + & - & - & - & + & + & - \\
\hline L-Arabinose & + & $\mathrm{v}(4)$ & + & + & $\mathrm{v}$ & + & + & - & - & + & $v$ & + & + \\
\hline Ribose & - & $v(1)$ & - & - & + & - & - & - & - & - & - & - & - \\
\hline D-Xylose & + & $v(4)$ & + & + & + & + & + & - & + & + & + & + & - \\
\hline Adonitol & + & - & - & + & + & + & - & - & - & - & - & + & - \\
\hline D-Galactose & + & + & $\mathrm{v}$ & + & + & $v$ & + & - & $\mathrm{v}$ & + & + & + & + \\
\hline D-Fructose & + & $v(2)$ & + & $v(3)$ & + & + & - & + & + & + & + & + & + \\
\hline Rhamnose & + & + & $\mathrm{v}$ & + & + & + & + & - & + & + & - & + & + \\
\hline Mannitol & + & - & - & - & + & + & - & - & + & - & - & - & - \\
\hline Sorbitol & + & - & - & - & + & $\mathrm{v}$ & - & - & - & - & - & - & - \\
\hline Methyl D-mannoside & + & + & - & - & - & + & + & - & + & + & + & + & + \\
\hline Methyl D-glucoside & + & + & + & $\mathrm{v}$ & + & + & + & + & + & + & + & + & + \\
\hline Arbutin & $\mathrm{v}$ & $v(3)$ & + & + & $\mathrm{v}$ & + & + & + & + & + & + & + & + \\
\hline Salicin & + & $v(4)$ & + & + & + & + & + & - & + & + & + & + & + \\
\hline D-Cellobiose & + & + & + & - & + & + & + & - & + & + & + & + & + \\
\hline
\end{tabular}


Table 5 (cont.)

\begin{tabular}{|c|c|c|c|c|c|c|c|c|c|c|c|c|c|}
\hline \multirow[t]{2}{*}{ Feature } & \multicolumn{13}{|c|}{ Taxon } \\
\hline & $\begin{array}{c}P . \\
\text { heparinus } \\
\text { Ia1 (2) }\end{array}$ & $\begin{array}{c}P . \\
\text { africanus } \\
\text { Ia3 (6) }\end{array}$ & $\begin{array}{c}P . \\
\text { piscium } \\
\text { (2) }\end{array}$ & $\begin{array}{l}P . \\
\text { saltans } \\
\text { III (4) }\end{array}$ & $\begin{array}{l}\text { Pedobacter } \\
\text { sp. Ia2 } \\
\text { (2) }\end{array}$ & $\begin{array}{c}\text { Pedobacter } \\
\text { sp. Ib1 } \\
\text { (2) }\end{array}$ & $\begin{array}{c}\text { Pedobacter } \\
\text { sp. lb2 } \\
\text { LMG } \\
10342\end{array}$ & $\begin{array}{c}\text { Pedobacter } \\
\text { sp. II } \\
\text { LMG } \\
10351\end{array}$ & $\begin{array}{c}S . \\
\text { spiritivorum } \\
\text { (2) }\end{array}$ & $\begin{array}{c}S . \\
\text { multivorum } \\
\text { (2) }\end{array}$ & $\begin{array}{c}S . \\
\text { mizutae } \\
(2)\end{array}$ & $\begin{array}{c}S . \\
\text { thalpophilum } \\
\text { (2) }\end{array}$ & $\begin{array}{c}S . \\
\text { faecium } \\
(1)\end{array}$ \\
\hline Maltose & + & $v(5)$ & + & + & + & + & + & - & + & + & + & + & + \\
\hline Lactose & + & + & + & + & + & + & + & - & + & + & + & + & + \\
\hline D-Melibiose & + & + & + & $v(3)$ & + & + & + & - & + & + & + & + & + \\
\hline Sucrose & + & + & + & $v(3)$ & + & + & + & - & + & + & + & + & + \\
\hline Trehalose & + & + & + & $v(2)$ & + & + & + & - & + & + & + & + & + \\
\hline Inulin & - & - & - & - & - & - & - & - & $\mathrm{v}$ & $\mathrm{v}$ & - & + & + \\
\hline D-Melezitose & - & - & - & - & - & - & - & - & + & + & + & + & + \\
\hline D-Raffinose & - & - & + & $\mathrm{v}(1)$ & - & + & - & - & + & + & + & + & + \\
\hline Starch & - & $\mathrm{v}(1)$ & + & - & - & + & + & + & + & + & + & + & + \\
\hline Glycogen & - & - & - & - & - & $\mathrm{v}$ & - & - & - & $\mathrm{v}$ & - & - & - \\
\hline$\beta$-Gentobiose & + & $v(5)$ & + & + & + & + & + & - & + & + & + & + & + \\
\hline D-Turanose & + & + & + & $v(3)$ & + & + & + & - & + & + & + & + & + \\
\hline D-Lyxose & - & - & - & - & - & - & - & - & - & - & + & - & - \\
\hline L-Fucose & + & $\mathrm{v}(2)$ & - & - & $\mathrm{v}$ & $\mathrm{v}$ & - & - & - & - & - & - & - \\
\hline D-Arabitol & - & - & - & - & v & - & - & - & + & - & - & - & - \\
\hline 2-Keto-gluconate & - & - & - & - & - & $\mathrm{v}$ & - & - & - & - & - & - & - \\
\hline 5-Keto-gluconate & - & - & - & - & - & - & + & - & - & - & - & - & - \\
\hline Succinate & - & $v(1)$ & - & - & - & - & - & - & - & $\mathrm{v}$ & - & - & - \\
\hline Fumarate & - & - & - & - & - & - & - & - & - & $\mathrm{v}$ & - & - & - \\
\hline L-Malate & - & - & - & - & - & - & - & - & - & $\mathrm{v}$ & - & - & - \\
\hline Pyruvate & + & $v(2)$ & - & - & + & $\mathrm{v}$ & + & - & - & - & $\mathrm{v}$ & - & - \\
\hline Citrate & - & - & - & - & - & - & - & - & - & - & $\mathrm{v}$ & - & - \\
\hline L- $\alpha$-Alanine & - & $\mathrm{v}(1)$ & - & - & - & - & - & - & - & - & - & - & - \\
\hline L-Serine & $\mathrm{v}$ & + & $\mathrm{v}$ & - & - & - & - & - & - & - & $\mathrm{v}$ & - & - \\
\hline L-Threonine & $\mathrm{v}$ & + & $\mathrm{v}$ & - & + & - & - & - & - & $\mathrm{v}$ & - & - & - \\
\hline L-Tyrosine & - & + & - & - & - & - & - & + & - & $\mathrm{v}$ & + & - & - \\
\hline 1-Histidine & - & $\mathrm{v}$ & - & - & - & - & - & + & - & $\mathrm{v}$ & + & - & - \\
\hline L-Aspartate & - & v & - & - & - & - & - & + & - & $\mathrm{v}$ & - & - & - \\
\hline L-Glutamate & - & + & + & - & + & + & + & + & - & + & + & - & + \\
\hline L-Ornithine & - & $v(1)$ & - & - & - & - & - & + & - & - & + & - & - \\
\hline L-Lysine & - & - & - & - & - & - & - & - & - & - & $\mathrm{v}$ & - & - \\
\hline L-Arginine & - & $v(1)$ & - & - & - & - & - & - & - & - & $\mathrm{v}$ & - & - \\
\hline L-Proline & - & $v(1)$ & + & - & - & - & - & + & - & - & + & - & - \\
\hline Creatine & - & $v(1)$ & - & - & - & - & - & - & - & - & - & - & - \\
\hline $\mathrm{G}+\mathrm{C}(\mathrm{mol} \%)$ & $42 \cdot 3-43 \cdot 0$ & $43 \cdot 7 \cdot-44 \cdot 2$ & $40 \cdot 4-41 \cdot 0$ & $36 \cdot 9-37 \cdot 1$ & $42 \cdot 3-42 \cdot 9$ & $37.4-37.5$ & $39 \cdot 5$ & $41 \cdot 2$ & $39 \cdot 8$ & $39 \cdot 9-40 \cdot 5$ & $39 \cdot 3-40$ & $4444 \cdot 2$ & $37 \cdot 3$ \\
\hline
\end{tabular}

* Data from Takeuchi \& Yokota (28).

heparinase-producing, obligately aerobic, Gram-negative rods, varying in form and length from 0.7 to $6 \mu \mathrm{m}$ and about $0.5 \mu \mathrm{m}$ wide with rounded or slightly tapering ends. No flagella or pili have been observed. Gliding motility has been observed in strains of some species. The colour of the colonies on modified Trypticase soy agar (TSA) and on nutrient agar varies from dirty yellow to creamy white. Pigments do not give the typical flexirubin reaction with $20 \% \mathrm{KOH}$. Sizes of the colonies vary from 1 to $5 \mathrm{~mm}$ in diameter on both media indicated above. On modified TSA, colonies are round, convex or slightly umbonate with entire margins. On nutrient agar, colonies are round to slightly irregular and spreading, convex to umbonate to flat with entire to scalloped margins. All members (except $P$. piscium) grow on heparin, which is degraded by inducible enzymes. Good growth occurs on nutrient agar or regular and modified TSA, but random isolates may inexplicably loose viability. All or most strains contain cytochrome- $c$ oxidase, catalase, acid and alkaline phosphatases, esterase lipase (C8), leucinearylamidase, $\alpha$-glucosidase, $\beta$-galactosidase, $N$-acetyl $\beta$-glucosaminidase, lysine decarboxylase and phosphoamidase. They produce acetoin from pyruvate, degrade chondroitin sulfate, hydrolyse aesculin, and assimilate D-glucose, D-mannose, amygdalin and glucosamine. None or almost none of the strains produce $\mathrm{H}_{2} \mathrm{~S}$ from thiosulfate and indole from tryptophan. Urease, lipase, $\beta$-glucuronidase, $\alpha$-fucosidase, lysine deaminase, arginine dihydrolase, phenylalanine deaminase and tryptophan deaminase are absent. No reduction of nitrate, growth on MacConkey agar, or gelatin liquefaction occurs. No assimilation or acid production is detected for a large number of substrates tested (Table 5). Particular taxa assimilate or produce acid from some carbohydrates, which can be used as differentiating features (Table 5). Organic acids, except pyruvate, and a few amino acids and amines are utilized by only some strains. Sensitivity to antibiotics is described in Table 6.

All the strains contain iso- $15: 0$, iso- $15: 0(2-\mathrm{OH})$, iso$15: 0(3-\mathrm{OH}), 16: 0,16: 1 \omega 5 \mathrm{c}, 16: 1 \omega 7 \mathrm{c}, 16: 0(3-\mathrm{OH})$, iso-17:0(3-OH) and iso- $17: 1 \omega 9 \mathrm{c}$ as major cellular 
Table 6. Sensitivity to antibiotics of the Pedobacter taxa (except $P$. piscium) studied

All strains studied are sensitive to sulfamethoxazole $(128 \mu \mathrm{g})$ and cotrimoxazole $(160 \mu \mathrm{g})$ and are resistant to kanamycin $(2 \mu \mathrm{g})$, amikacin $(16 \mu \mathrm{g})$, tobramycin $(4 \mu \mathrm{g})$ and sisomicin $(10 \mu \mathrm{g})$. For the taxa, the name, SDS-PAGE or DNA homology sub-group number, and LMG number or number of strains investigated (in parentheses) is shown. +, Positive; -, negative; v, variable; the number of strains positive for the respective feature are shown in parentheses.

\begin{tabular}{|c|c|c|c|c|c|c|c|}
\hline \multirow[t]{2}{*}{ Susceptibility ( $\mu \mathrm{g}$ ) } & \multicolumn{7}{|c|}{ Taxon } \\
\hline & $\begin{array}{l}\text { P. heparinus } \\
\text { Ia1 (2) }\end{array}$ & $\begin{array}{c}P . \text { africanus } \\
\text { Ia3 (6) }\end{array}$ & $\begin{array}{c}P \text {. saltans III } \\
\text { (4) }\end{array}$ & $\begin{array}{l}\text { Pedobacter } \\
\text { sp. Ia2 (2) }\end{array}$ & $\begin{array}{l}\text { Pedobacter } \\
\text { sp. Ib1 (2) }\end{array}$ & $\begin{array}{l}\text { Pedobacter sp. } \\
\text { Ib2 LMG } 10342\end{array}$ & $\begin{array}{l}\text { Pedobacter sp. } \\
\text { II LMG } 10351\end{array}$ \\
\hline Ampicillin (8) & - & - & $v(3)$ & - & - & - & + \\
\hline Chloramphenicol (8) & + & $\mathrm{v}(1)$ & + & - & - & + & + \\
\hline Cephalothin (16) & + & $v(2)$ & - & - & - & - & + \\
\hline Penicillin $(0.03)$ & + & $\mathrm{v}(3)$ & $\mathrm{v}(1)$ & - & - & - & - \\
\hline Carbenicillin (128) & + & - & + & - & + & + & + \\
\hline Tetracycline (2) & + & - & + & - & - & + & + \\
\hline Gentamicin (4) & - & - & $\mathrm{v}(1)$ & - & - & - & - \\
\hline Cephamandole (16) & + & - & $v(3)$ & - & $\mathrm{v}$ & + & + \\
\hline Methicillin (4) & + & $\mathrm{v}(5)$ & $v(3)$ & - & - & + & - \\
\hline Erythromycin (4) & + & - & $\mathrm{v}(3)$ & - & + & + & + \\
\hline Cephalexin (16) & + & $v(2)$ & $\mathrm{v}(1)$ & - & + & + & + \\
\hline Cefoxitin (10) & + & $\mathrm{v}(1)$ & - & - & $\mathrm{v}$ & + & - \\
\hline
\end{tabular}
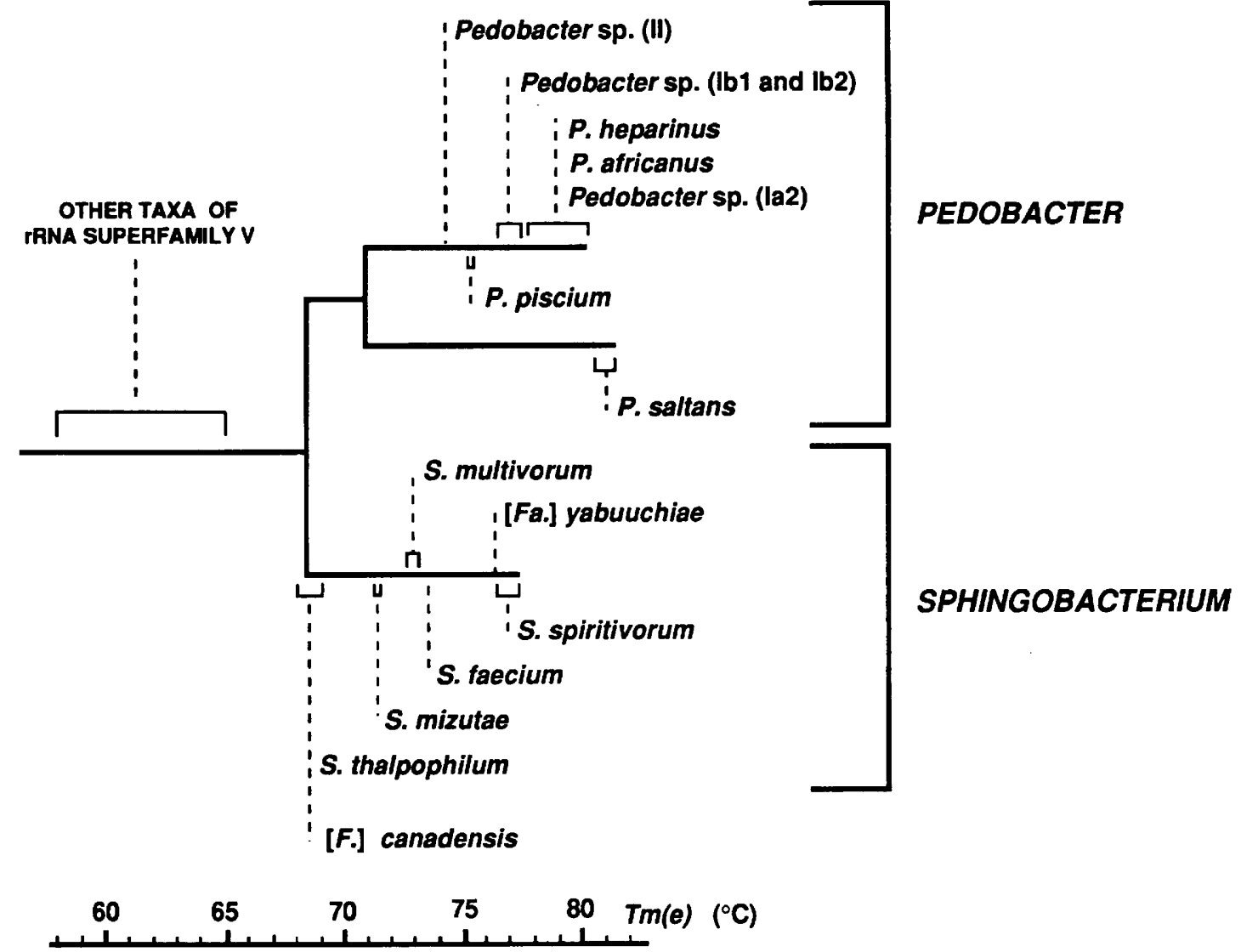

Fig. 1. rRNA cistron similarity dendrogram representing the family Sphingobacteriaceae as part of rRNA superfamily V. SDS-PAGE or DNA hybridization sub-group numbers are shown in parentheses for unnamed Pedobacter species. Abbreviations: Fa., Flavobacterium; F., Flexibacter; P., Pedobacter; S., Sphingobacterium. The results are expressed as $T_{\mathrm{m}(e)}$ $\left({ }^{\circ} \mathrm{C}\right)$ versus the reference rRNAs (see Table 2 ). 
fatty acids. All strains tested contain sphingolipids and the MK-7 menaquinone system. The $\mathrm{G}+\mathrm{C}$ content is $36-45 \mathrm{~mol} \%\left(T_{\mathrm{m}}\right)$. Temperature range is normally between 5 and $30^{\circ} \mathrm{C}$ but some strains may grow at $37^{\circ} \mathrm{C}$. The habitat is soil, activated sludge, or fish. The type species is Pedobacter heparinus.

\section{Description of Pedobacter heparinus (Payza and Korn 1956; emend. Christensen 1980) comb. nov.}

Pedobacter heparinus (he.pa.ri'nus. Gr. n. hepar liver; M.L. masc. adj. heparinus of or pertaining to degradation of heparin, acidic mucoheteropolysaccharide with sulfate groups from various animal tissues).

Cells vary from short rods of $0.7 \mu \mathrm{m}$ to relatively long rods of $6 \mu \mathrm{m}$ and $0.5 \mu \mathrm{m}$ wide with rounded or slightly tapered ends. Protrusions can be observed on the cell surface. Gliding motility has been observed. Colour of colonies varies from translucent yellowish to dirty yellow on modified TSA, and from translucent yellow to bright yellow on nutrient agar. Colonies on modified TSA are $1-4 \mathrm{~mm}$ in diameter, round, convex or slightly umbonate with entire margins and convex with entire margins. On nutrient agar, colonies are round to spreading, convex to umbonate to flat with entire to scalloped margins.

General characteristics are those as given for the genus. The organism can be differentiated from most other taxa of the genus by its ability to grow on sorbitol and L-fucose, and the absence of valine arylamidase. Additional differentiating features are given in Tables 4,5 and 6 . Some other characteristics are described by Christensen (2) and Takeuchi \& Yokota (28). The $\mathrm{G}+\mathrm{C}$ content is $42-43 \mathrm{~mol} \%\left(T_{\mathrm{m}}\right)$; the genome size of the type strain LMG 10339 is $2.23 \times 10^{9} \mathrm{Da}(21)$. The organism is isolated from soil. Type strain is LMG 10339 ( = ATCC 13125).

\section{Description of Pedobacter africanus gen. nov., sp. nov.}

Pedobacter africanus (a.fri.ca'nus. M.L. masc. adj. africa from Africa).

Colonies on modified TSA are $2-5 \mathrm{~mm}$ in diameter, translucent, yellow, smooth, round, convex to slightly umbonate with entire margins. On nutrient agar colonies are $2-4 \mathrm{~mm}$ in diameter, translucent, yellow, smooth, round, convex, with entire to slightly scalloped margins. Cell morphology is as described for the genus. No gliding motility has been observed. General features are those as given for the genus. Strains of the species can be discriminated by their ability to assimilate several amino acids (Table 5). Additional characteristics are given in Tables 4,5 and 6 . The $\mathrm{G}+\mathrm{C}$ content is $43-45 \mathrm{~mol} \%$. Strains are isolated from soil and activated sludge. Type strain is $\mathrm{LMG}$ 10353.

\section{Description of Pedobacter piscium (Takeuchi and Yokota 1992) comb. nov.}

Pedobacter piscium (pis'ci.um. L. n. piscis a fish; L. gen. pl. piscium of fishes).

Colonies on modified TSA are $2-5 \mathrm{~mm}$ in diameter, translucent, yellow, smooth, round, low convex with entire margins. On nutrient agar, colonies are 2-4 mm in diameter, opaque, smooth, round, convex, with entire margins. A yellow or creamy white non-fluorescent pigment is produced. Cell size is $0.5 \mu \mathrm{m}$ wide and $0 \cdot 5-1 \mu \mathrm{m}$ long. Cell morphology is as described for the genus. No gliding has been observed. Features are as given for the genus. P. piscium is the only Pedobacter species producing trypsin. Characteristic for its fatty acid content is a measurable amount of anteiso17:1 $\omega 9 \mathrm{c}$. More detailed characteristics are given in Tables 4 and 5 and by Takeuchi \& Yokota (28). The growth temperature ranges between 5 and $30^{\circ} \mathrm{C}$, no growth occurs at $37^{\circ} \mathrm{C}$. The $\mathrm{G}+\mathrm{C}$ content is $40-43$ $\mathrm{mol} \%$. Strains are probably isolated from fish. Type strain is LMG 14023 (= ATCC 13125, IFO 12017).

\section{Description of Pedobacter saltans sp. nov.}

Pedobacter saltans (sal'tans. L. v. saltare to dance; saltans $\mathrm{L}$. adj. dancing, referring to its peculiar dancing or gliding motility).

Colonies on modified TSA are smooth, light yellow to yellow, translucent, round, $2-5 \mathrm{~mm}$ in diameter, convex to slightly umbonate with entire margins. On nutrient agar colonies are smooth, yellow, round, 2-4 mm in diameter, convex with entire to scalloped margins. Three out of four isolates exhibit a peculiar gliding motility without any special manipulations. Features are those as given for the genus. $P$. saltans can phenotypically be differentiated from most Pedobacter strains by its inability to assimilate $\mathrm{D}$-cellobiose and the ability to utilize glycerol. Additional characteristics are given in Tables 4,5 and 6 . The $\mathrm{G}+\mathrm{C}$ content is $36-38 \mathrm{~mol} \%$. Strains are isolated from soil. Type strain is LMG 10337.

\section{Description of Sphingobacteriaceae fam. nov.}

Descriptive information for the family is taken from the literature $(1,3,5,9,12,17,28,32)$ and the present paper. Organisms belonging to the family are Gramnegative. Cells are short to relatively long rods and are usually $0.3-0.6 \mu \mathrm{m}$ wide and $0.5-6 \mu \mathrm{m}$ long (except [Flexibacter] canadensis which is filamentous) and are non-sporulating. Flagella are absent. Non-motile or motile by gliding. Aerobic growth with optimum temperature in a range of $10-30^{\circ} \mathrm{C}$ ([Flexibacter] canadensis also grows as a facultative anaerobe). Colonies are usually yellow pigmented. Chemoorgano- 
trophic. All members produce catalase, oxidase and phosphatase, are indole-negative, and can utilize a large number of carbohydrates. Few organic acids and amino acids are utilized. Dominant fatty acids are iso$15: 0$, iso- $15: 0(2-\mathrm{OH})$, iso- $15: 0(3-\mathrm{OH}), 16: 0,16: 1 \omega 7 \mathrm{c}$, $16: 0(3-\mathrm{OH})$ and iso-17:0(3-OH). Menaquinone 7 is the major respiratory quinone. Presence of sphingolipids. Homospermidine is the major polyamine. The $\mathrm{G}+\mathrm{C}$ content is $36-45 \mathrm{~mol} \%$. Members of this family are commonly isolated from soil or activated sludge and from clinical specimens. No species are considered as true pathogens.

The type genus is Sphingobacterium. Other members are Pedobacter and [Flexibacter] canadensis. All these organisms belong to the same rRNA branch within rRNA superfamily V (the Cytophaga-Flavobacterium-Bacteroides group). Differential characteristics between the taxa belonging to the family Sphingobacteriaceae are given in Tables 4, 5 and 6 and the literature $(3,12,24,28,32)$. The family Sphingobacteriaceae belongs to the order Cytophagales Leadbetter $1974,99^{\mathrm{AL}}(22)$.

\section{ACKNOWLEDGEMENTS}

K.K. is indebted to the Fund for Medical Scientific Research, Belgium, for research and personnel grants. Part of the research was performed in the framework of the CEC contract BIO2-CT 94-3098 and also co-financed by the Prime Minister's Services - Federal Office for Scientific, Technical and Cultural Affairs, Belgium.

\section{REFERENCES}

1. Bernardet, J.-F., Segers, P., Vancanneyt, M., Berthe, F., Kersters, K. \& Vandamme, P. (1996). Cutting a gordian knot: emended classification and description of the genus Flavobacterium, emended description of the family Flavobacteriaceae, and proposal of Flavobacterium hydatis nom. nov. (basonym Cytophaga aquatilis Strohl and Tait 1978). Int $J$ Syst Bacteriol 46, 128-148.

2. Christensen, P. (1980a). Description and taxonomic status of Cytophaga heparina (Payza and Korn) comb. nov. (basionym: Flavobacterium heparinum Payza and Korn 1956). Int $J$ Syst Bacteriol 30, 473-475.

3. Christensen, P. (1980b). Flexibacter canadensis sp. nov. Int $J$ Syst Bacteriol 30, 429-432.

4. Cowan, S.T. (1979). Cowan \& Steel's Manual for the Identification of Medical Bacteria, 2nd edn. Cambridge: Cambridge University Press.

5. Dees, S. B., Carlone, G. M., Hollis, D. \& Moss, C. W. (1985). Chemical and phenotypic characteristics of Flavobacterium thalpophilum compared with those of other Flavobacterium and Sphingobacterium species. Int $J$ Syst Bacteriol 35, 16-22.

6. De Ley, J. (1992). The Proteobacteria: ribosomal RNA cistron similarities and bacterial taxonomy. In The Prokaryotes, 2nd edn, vol. 2, pp. 2111-2140. A. Balows, H. G. Trüper, M. Dworkin, W. Harder \& K.-H. Schleifer. Berlin: Springer.
7. Dobson, S. J., Colwell, R. R., McMeekin, T. A. \& Franzman, P. D. (1993). Direct sequencing of the polymerase chain reaction-amplified 16S rRNA gene of Flavobacterium gondwanense sp. nov. and Flavobacterium salegens sp. nov., two new species from a hypersaline antarctic lake. Int $J$ Syst Bacteriol 43, 77-83.

8. Gherna, R. \& Woese, C. R. (1992). A partial phylogenetic analysis of the 'Flavobacter-Bacteroides' phylum: basis for taxonomic restructuring. Syst Appl Microbiol 15, 513-51.

9. Hamana, K. \& Matsuzaki, S. (1991). Polyamine distributions in the Flavobacterium-Cytophaga-Sphingobacterium complex. Can J Microbiol 37, 885-888.

10. Holmes, B., Owen, R. J. \& Hollis, D. G. (1982). Flavobacterium spiritivorum, a new species isolated from human clinical specimens. Int J Syst Bacteriol 32, 157-165.

11. Holmes, B., Owen, R. J. \& Weaver, R. E. (1981). Flavobacterium multivorum, a new species isolated from human clinical specimens and previously known as group IIk, biotype 2. Int J Syst Bacteriol 31, 21-34.

12. Jacobi, C. A., Reichenbach, H., Tindall, B. J. \& Stackebrandt, E. (1996). Candidatus comitans, a bacterium living in coculture with Chondromyces crocatus (myxobacteria). Int $J$ Syst Bacteriol 46, 119-122.

13. Joubert, J. J., van Rensburg, E. J. \& Pitout, M. J. (1984). A plate method for demonstrating the breakdown of heparin and chondroitin sulfate by bacteria. Microbiol Methods 2, 197-202.

14. Joubert, J. J. (1985). Kenmerking van heparinase produserende mikro-organismes. MD thesis, University of Pretoria.

15. Kersters, K., Hinz, K.-H., Hertle, A., Segers, P., Lievens, A., Siegmann, O. \& De Ley, J. (1984). Bordetella avium sp. nov. isolated from the respiratory tracts of turkeys and other birds. Int $J$ Syst Bacteriol 34, 56-70.

16. Manz, W., Amann, R., Ludwig, W., Vancanneyt, M. \& Schleifer, K.-H. (1996). Application of a suite of 16S rRNAspecific oligonucleotide probes designed to investigate bacteria of the phylum cytophaga-flavobacter-bacteroides in the natural environment. Microbiology 142, 1097-1106.

17. Nakagawa, Y. \& Yamasato, K. (1993). Phylogenetic diversity of the genus Cytophaga revealed by $16 \mathrm{~S}$ rRNA sequencing and menaquinone analysis. J Gen Microbiol 139, 1155-1161.

18. Nakagawa, Y. \& Yamasato, K. (1996). Emendation of the genus Cytophaga and transfer of Cytophaga salmonicolor to Marinilabilia gen. nov.: phylogenetic analysis of the Flavobacterium-Cytophaga complex. Int J Syst Bacteriol 46, 599-603.

19. Paster, B. J., Ludwig, W., Weisburg, W. G., Stackebrandt, E., Hespell, R. B., Hahn, C. M., Reichenbach, H., Stetter, K. O. \& Woese, C. R. (1985). A phylogenetic grouping of the bacteroides, cytophagas, and certain flavobacteria. Syst Appl Microbiol 6, 34-42.

20. Payza, A. N. \& Korn, E. D. (1956). The degradation of heparin by bacterial enzymes. 1 . Adaptation and lyophilized cells. $J$ Biol Chem 223, 853-864.

21. Reichenbach, H. (1989a). Genus I. Cytophaga Winogradsky $1929,577^{\mathrm{AL}}$. Edited by J. T. Staley, M. P. Bryant, N. Pfennig \& J. G. Holt. In Bergey's Manual of Systematic Bacteriology, vol. 3, pp. 2015-2020. Baltimore: Williams \& Wilkins.

22. Reichenbach, H. (1989b). Order I. Cytophagales Leadbetter 1974, 99 ${ }^{\text {AL }}$. Edited by J. T. Staley, M. P. Bryant, N. Pfennig 
\& J. G. Holt. In Bergey's Manual of Systematic Bacteriology, vol. 3, pp. 2011-2013. Baltimore: Williams \& Wilkins.

23. Segers, P., Mannheim, W., Vancanneyt, M., De Brandt, K., Hinz, K.-H., Kersters, K. \& Vandamme, P. (1993). Description of Riemerella anatipestifer gen nov., comb. nov., the causative agent of septicaemia anserum exsudativa and its phylogenetic affiliation within the Flavobacterium-Cytophaga rRNA hybridization group. Int $J$ Syst Bacteriol 43, 768-776.

24. Shivaji, S., Ray, M. K., Shyamale Rao, N., Saisree, L., Jagannadham, M. V., Seshu Kumar, G., Reddy, G. S. N. \& Bhargava, P. M. (1992). Sphingobacterium antarcticus sp. nov, a psychotrophic bacterium from soils of Schirmacher Oasis, Antarctica. Int J Syst Bacteriol 42, 102-106.

25. Sonnenwirth, A. C. (1980). Bacteriological methods. In Gradwohl's Clinical Laboratory Methods and Diagnosis, vol. 2, 8th edn, pp. 1338-1377. Edited by A. C. Sonnenwirth \& W. Jarret. London: C. V. Mosby.

26. Steyn, P. L., Pot, B., Segers, P., Kersters, K. \& Joubert, J. J. (1992). Some novel aerobic heparin-degrading bacteria. Syst Appl Microbiol 15, 137-143.

27. Steyn, P. L., Joubert, J. J., Segers, P., Pot, B., Vancanneyt, M., Willems, A., Hoste, B. \& Kersters, K. (1993). The taxonomic position of some gram-negative aerobic heparinase producing bacteria. In Advances in the Taxonomy and Significance of Flavobacterium, Cytophaga and Related Bacteria, pp. 137-151. Edited by P. J. Jooste. Bloemfontein, South Africa: University of Orange Free State Press.
28. Takeuchi, M. \& Yokota, A. (1992). Proposals of Sphingobacterium faecium sp. nov., Sphingobacterium piscium sp. nov., Sphingobacterium heparinum comb. nov., Sphingobacterium thalpophilum comb. nov. and two genospecies of the genus Sphingobacterium, and synonymy of Flavobacterium yabuuchiae and Sphingobacterium spiritivorum. $J$ Gen Appl Microbiol 38, 465-482.

29. Vandamme, P. \& De Ley, J. (1992). Proposal for a new family, Campylobacteraceae. Int $J$ Syst Bacteriol 41, 451-455.

30. Vandamme, P., Bernardet, J.-F., Segers, P., Kersters, K. \& Holmes, B. (1994). New perspectives in the classification of the flavobacteria: description of Chryseobacterium gen. nov., Bergeyella gen nov. and Empedobacter nom. rev. Int $J$ Syst Bacteriol 44, 827-831.

31. Vannieuwenhuyze, F. \& Sandra, P. (1987). Selectivity optimalization for the capillary gas chromatographic analysis of bacterial cellular fatty acids. Chromatographia 23, 850855.

32. Yabuuchi, E., Kaneko, T., Yano, I., Moss, C. W. \& Miyoshi, N. (1983). Sphingobacterium gen. nov., Sphingobacterium spiritivorum comb. nov., Sphingobacterium multivorum comb. nov., Sphingobacterium mizutae sp. nov., and Flavobacterium indologenes sp. nov.: glucose-nonfermenting gram-negative rods in CDC groups IIk-2 and IIb. Int $J$ Syst Bacteriol 33, 580-598.

33. Yabuuchi, E. \& Moss, C. W. (1982). Cellular fatty acid composition of strains of three species of Sphingobacterium gen. nov. and Cytophaga johnsonae. FEMS Microbiol Lett $13,87-91$. 